\title{
複断面河道の粗度係数に関する数值計算 NUMERICAL SIMULATION OF MANNING'S ROUGHNESS COEFFICIENT OF COMPOUND RIVER CHANNEL
}

\author{
玉井昌宏 1 ・手束理志 2 \\ Masahiro TAMAI and Satoshi TEDUKA \\ 1正会員 博(工) 大阪大学准教授 大学院工学研究科地球総合工学専攻 (广 $565 \square 0871$ 吹田市山田丘 2-1) \\ 2学生会員 大阪大学大学院工学研究科地球総合工学専攻前期課程 (₹ 565口 0871 吹田市山田丘 2-1)
}

\begin{abstract}
Manning's roughness coefficient is influenced by roughness condition of perimeter, shapes of longitudinal and cross sections, flow conditions represented by parameters such as the Reynolds Number and so on. There are few preceding studies dealing with relationship between the roughness coefficient and other factors than the roughness condition. The purpose of this study is to examine relationship between the Manning's overall roughness coefficient and configurations of river channels which have different roughness perimeters by numerical simulation. Characteristics of variations in the Manning's coefficient according to water depth and applicability of composite roughness coefficient are discussed.
\end{abstract}

Key Words : Manning's roughness coefficient, compound river channel, numerical simulation

\section{1. 研究の目的}

マニングの粗度係数は治水計画において最も重要なパ ラメータの一つであり, かつ極めて不確実なパラメータ である . 模型実験によっても，あるいは洪水痕跡線に よっても , 実河川の粗度係数を精度良く推定することは 難しい.

friction factorに関する従来の考察から, 粗度係数につ いても, 粗度高さ, 断面積 , 径深など断面形状に関する 要因 , Re数, Fr数など流れの状況に関する要因等の関数 であることか漼測される . 粗度高さ , あるいは潤辺の状 況と粗度係数との関係については種々検討されているも のの, 弚の他の要因に関する研究例は非常に少ない . 樣々な断面形状を持つ開水路乱流に関する精緻な実験結 果や数値解析結果は多数得られているものの, 流動の内 部構造に関する議論に留まっており，河道全体のエネル ギー損失や粗度係数への影響を検討しているものはほと んど無い. ${ }^{1)}$

複断面河道の粗度係数算定には, 通常, 合成粗度法が 用いられる．ところが, 同法の予測精度や「分割断面間

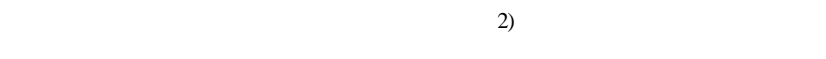
分割を行うべきかといった事柄について，十分議論され ているわけではない .

本論文では, 汎用の数値計算ソフトウエアを用いて ,
複断面開水路のマニングの粗度係数に関する数値計算を 行い, 水深による粗度係数の変動傾向, 合成粗度法の予 測精度について考察する。

\section{2. 数值計算の概要}

（1）数值モデル

数值計算には, CHAM社3次元汎用熱流体解析ソフト PHOENICS Ver.2006を用いる. 乱流モデルには標準k- $\epsilon$ モデルを，固定境界の境界条件には以下のような条件を 用いた。

$$
\begin{gathered}
U^{+}=U / U_{\tau}=\ln \left(8.6 y^{+}\right) / \kappa \\
k=U \tau^{2} / C_{\mu}{ }^{0.5} \\
\varepsilon=C_{\mu}^{0.75} k^{1.5} /(k Y)
\end{gathered}
$$

ここに, $U^{+}$：無次元速度， $U(m / s)$ ：流速， $U_{\tau}(\mathrm{m} / \mathrm{s})$ : 摩擦速度, $y^{+}$: 無次元距離, $\kappa$ : Karman定 数 $\left.(=0.41), C_{\mu}=0.09, \mathrm{k}^{2} \mathrm{~m}^{2} / \mathrm{s}^{2}\right)$ : 乱流エネルギー， $\varepsilon\left(\mathrm{m}^{2} / \mathrm{s}^{3}\right)$ : 乱れの散逸率である .

流入面での乱流エネルギーと光の散逸率は等流状態を 仮定し，次式より計算される .

$$
k=(I U)^{2}
$$




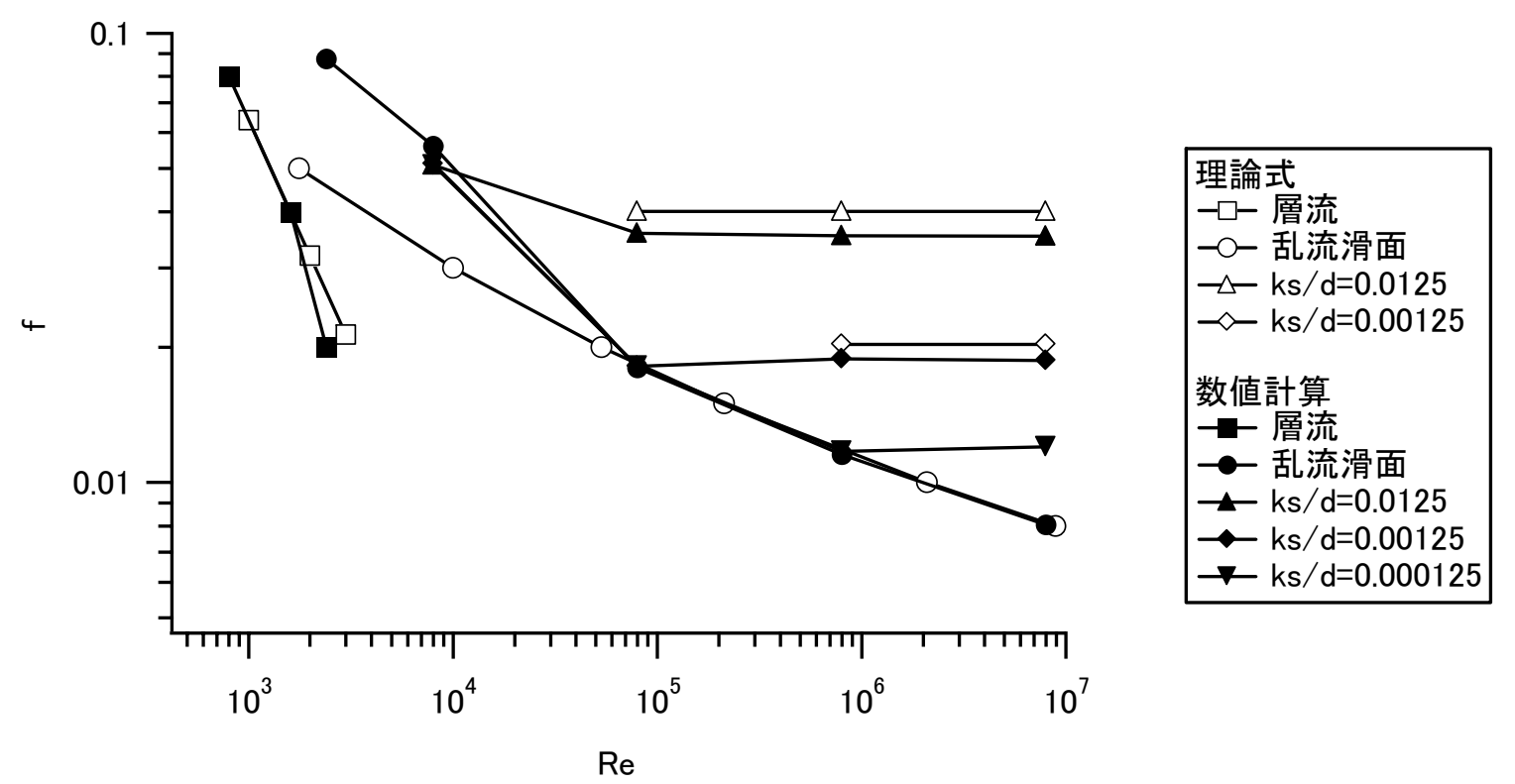

図-1 friction fact or di agram

$$
\varepsilon=c_{\mu}^{3 / 4} \frac{k^{3 / 2}}{0.1 R}
$$

ここに， $R(m)$ : 径深である.また,$I=0.03$ と仮定し ている . 流出面では , 流速 ，乱流エネルギーと散逸率の 流下方向勾配を0とする .

\section{（2）粗度係数算出のための方法}

粗度係数計算においては, 流下方向に一樣な断面形状 と河床勾配 , 粗度高さを持つ直線の複断面水路を想定す る . 但し , 低水路と高水敷の粗度高さは異なる . 複断面 水路の水面に相当する境界条件は, slip条件を持つ固定 境界面とする．等流条件か満足される場合には，nonslip条件の壁面せん断力と水路勾配による重力か釣り合

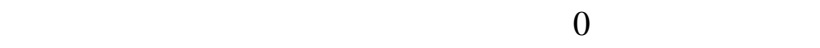
に流水の水深を決定してから，この等流条件を満足する ように , 流入境界の流速あるいは流量を調整する . 以上 のようにして得られた断面平均流速を用い，次式のよう に粗度係数を算出することとなる．

$$
n=\frac{R^{2 / 3} S^{1 / 2}}{U}
$$

ここに, $n$ : 粗度係数, $R(m)$ : 径深, $S$ : 河床勾配， $U(\mathrm{~m} / \mathrm{s})$ : 断面平均流速である.

\section{3. 計算精度の検証}

（1）円管におけるfricti on fact orの計算
本研究で用いる数値計算ソフトウエアは英国を中心に 幅広く使用されている汎用ソフトウエアであり，改めて 計算方法の妥当性を確忍する必要はない.ここでは, 数 値計算によって円管の friction factor diagram を作成する ことによって，計算精度について検証した .この計算に おいては, 水平円管の上流端より流量を与え, 円管内に 生じる圧力勾配より, friction factor $f$ を算出する .

円管における $f$ には , 次式のような関係がある .

$$
\begin{gathered}
f=\frac{64}{\operatorname{Re}} \text { (層流域) } \quad \text { (7) } \\
\frac{1}{\sqrt{f}}=2.03 \log _{10}\left(\frac{U d}{v} \sqrt{f}\right)-0.8 \quad \text { (滑面乱流) } \\
\frac{1}{\sqrt{f}}=2.03 \log _{10} \frac{d}{2 k_{s}}+1.74 \quad \text { (粗面乱流) }
\end{gathered}
$$

ここに, Re：レイノルズ数， $d(m)$ ：管径， $v\left(\mathrm{~cm}^{2} / \mathrm{s}\right)$ : 動粘性係数, $k_{\mathrm{s}}(\mathrm{m})$ : 粗度高さである.

図一1は, 数値計算により求めたfricition factorと(7)〜(9) 式の比較を示している. $10^{3}<\mathrm{Re}<10^{4}$ の遷移領域にお いて, 滑面乱流の計算結果力理論式に比較して大きく なっているのを除けは, 両者の一致は良好である.特に， 本研究で対象としている粗面乱流域において, 十分な計 算精度が得られていることか確認される。

（2）複断面水路における実験・計算値との比較

次に，複断面開水路における計算精度の検証のために， 既往の実験結果，計算結果 ${ }^{3)}$ との比較を行った . 計算条 件は, 参考文献3と同一であり, 図一2は, 計算に用いた 断面形状である.同図中，S1は水路中央，S2は水路中央 


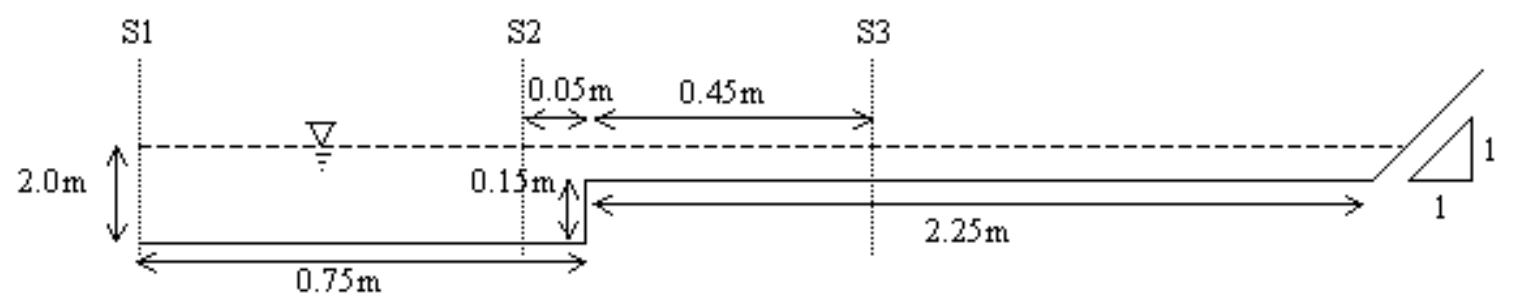

図-2 精度検証に用いた複断面

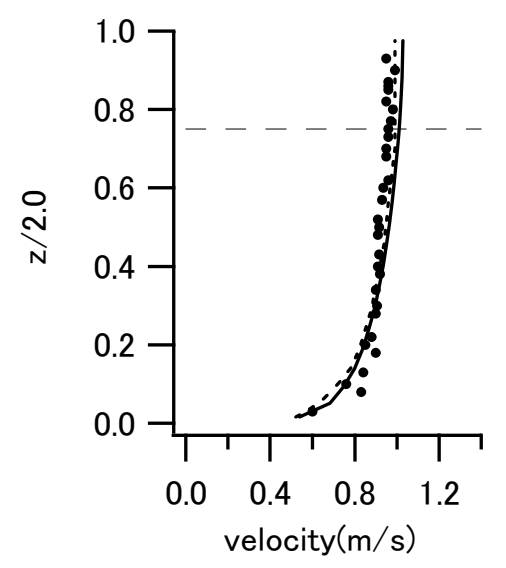

(a) S1断面流速鉛直分布

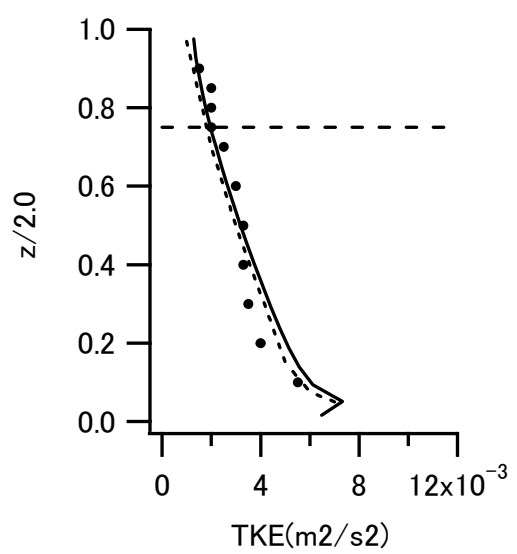

(d) S1断面乱流エネルギー鉛直分布

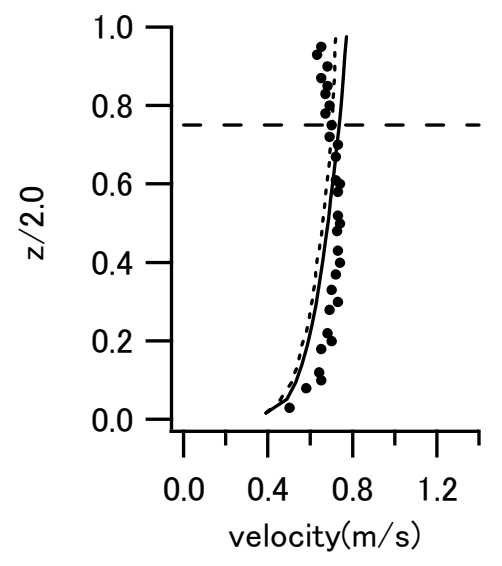

(b) S2断面流速鉛直分布

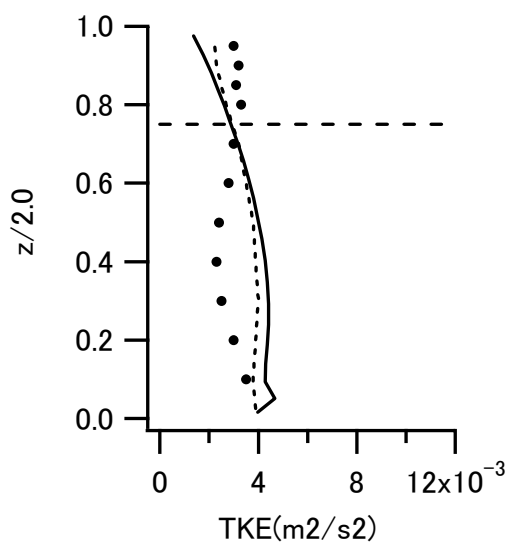

（e）S2断面乱流エネルギー鉛直分布

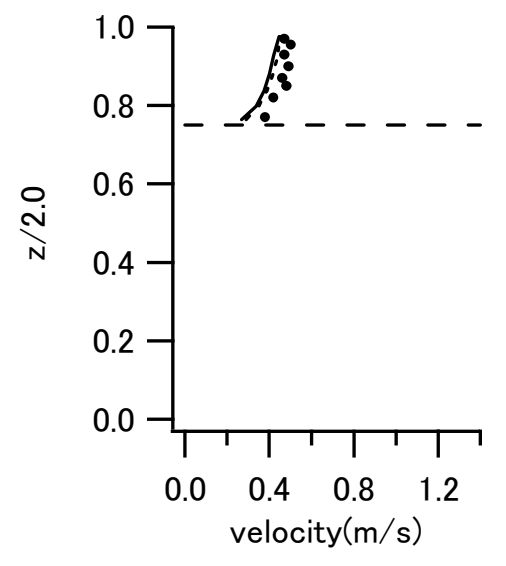

（c） S3断面流速鉛直分布

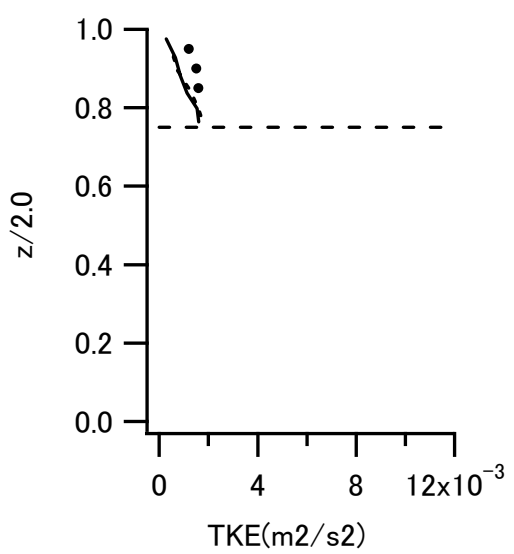

（f）S3断面乱流エネルギー鉛直分布

一計算結果 … Rameshwaranらl二よる計算結果 UKFCF実駚結果

図-3 精度検証結果

から $0.7 \mathrm{~m}, \mathrm{~S} 3$ は水路中央から $1.2 \mathrm{~m}$ 断面である .

図-3は既往の実験結果，計算結果と今回の計算結果と の比較である . 流下方向流速 , 乱流エネルギ一の鉛直分 布より，低水路中央付近S1と高水敷上S3では, 計算結果 は実測結果の傾向を良好に再現している . 高水敷と低水 路の接合部付近S2においては, Rameshwaranらによる計 算結果 , 今回の計算結果ともに，実測值に比較して，乱 流エネルギーについては過大に , 流速については過小に
なっている . Rameshwaranによれば，光の原因は二次流 が再現出来ていないからであるとしている．

2つの数値計算結果を比較すると分布傾向は一致して いるが, 絶対值には多少の差異がある . 全く同一の計算 条件であることから，用いたソフトウエアが異なってい ることと計算メッシュの構成意外に，この差異の原因は 考えられない . 


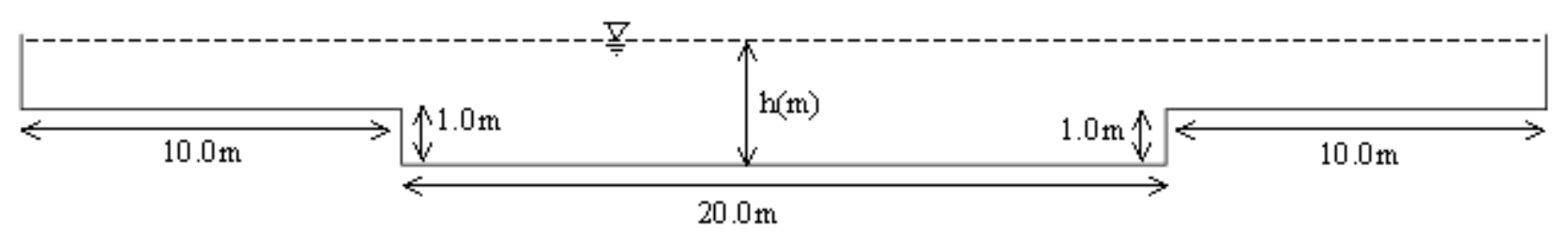

図-4 複断面A( 幅広)

\section{4. 複断面河道の粗度係数の変動傾向}

（1）計算条件

ここでは, 図-4のような幅広の複断面形状 (複断面 A）と図-5のような複断面形状 (複断面B) を用いる. 断面は左右対称であることから，断面中央に左右対称と なるため, 水路中央て切った片側断面だけを計算するこ とて計算効率の向上を图っている．また，水路勾配は $1 / 200$ とした . 河床と低水路護岸については, 同一の粗 度高さ $k_{1}=0.01$ を持つものとし，高水敷と堤防部分につ いても, 同一の粗度高さ $k_{2}=0.1$ を持つものとする

この計算においては, 図-4, 5の断面形状を用いて， 水深 $h$ を $0.02,0.05,0.2,0.5,1.0,1.2,1.5,2.0,3.0 \mathrm{~m}$ と9段階に変化させて，2 (2) て記述した方法により，流 入させる流量を試行錯誤的に求めた . 図一切觉の結果で ある

( 2) 粗度高さと粗度係数の関係

図-7は $k_{1}=k_{2}$ とした場合の, 粗度高さと粗度係数と の関係を示している.ここでは, 水深が2mとした場合 の計算結果である. 比較のために, 粗度高さと粗度係数 との関係であるマニング・ストリクラーの式)を併せて 示している . 同式は次式のとおりである .

$$
n=\frac{k_{s}^{1 / 6}}{7.66 \sqrt{g}}
$$

ここに， $k_{s}(m)$ : 相当粗度 (代表粒径) である.$k_{s}$ と $k$ の関係力明確てはなく, また, 本研究の立場は, 粗度係 数は粗度高さのみの関数ではないといことであるから， 両者が一致する必要はない．絶対值の規模か概ね一致し ていることと, 粗度高さに対する粗度係数の変動傾向を 概ね再現していることがわかる. 複断面Aと複断面Bの 值を比較すると, 複断面Aの值の方が大きいことが分か る. 後述する, 合成粗度法の誤差に関する検討では, こ の粗度係数值を用いている。

\section{(3) 粗度係数の水深による変化}

図-8は諸外国の河川て観測された水深と粗度係数との 関係を示している.いずれの観測結果についても，水深 の小さい範囲で, 水深の増加とともに粗度係数は減少 する . これは, 水深に対する相対的な粗度の高さが小さ

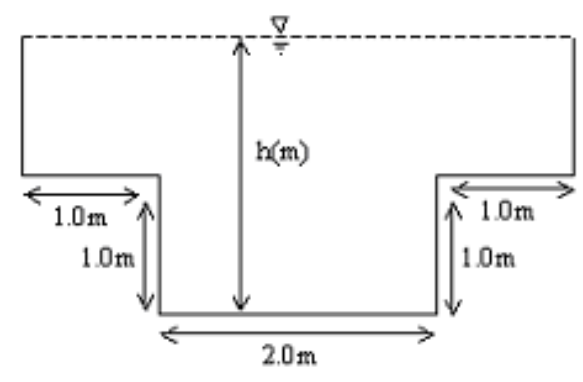

図-5 複断面B

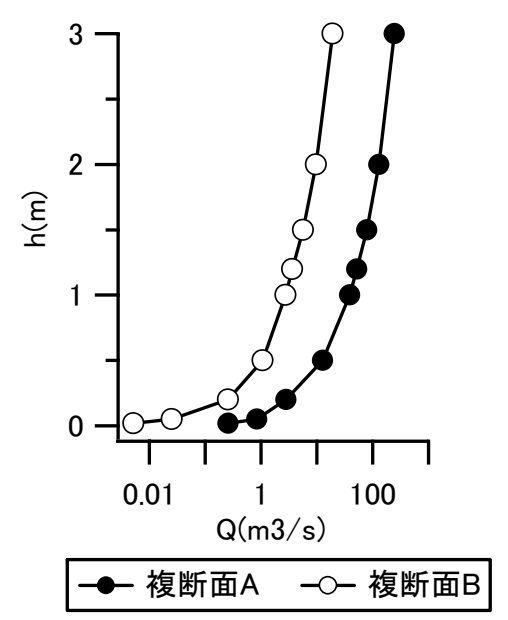

図-6 水深と流量との関係 ( 計算条件)

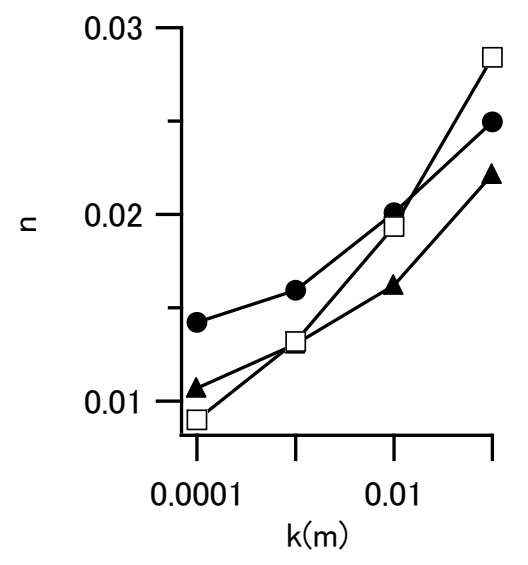

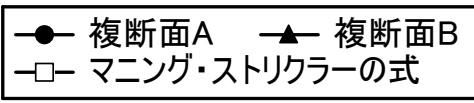

図-7 h=2 Onhうおる粗度高さと粗度係数との関係 
くなることによると推測される.Tennessee 川を除いて， 粗度係数には極小值が見られる.これは, 河道内のより 高い位置に大きな粗度要素力存在することが原因である と考えられる. 従って, 低水路て低い粗度高さ, 高水敷 で高い粗度高さとなっている複断面河道においても同樣 に変動傾向か現れることが予想される．

図-9は数值計算により算出した， $k_{1}=0.01, k_{2}=0.1$ とした場合の水深による粗度係数の変動を示している. 図-8と同樣に, 粗度高さは低水路内の $h \leq 0.5 \mathrm{~m}$ の範囲 では減少し，水面が高水敷を超えると増加に転じている ことがわかる.特に高水敷付近て粗度係数は急増する。 これは, 潤辺長の増加が流水断面積の増加に比較して急 激であるからである。

比較のために，図中には 2 つ方法で求めた合成粗度 值を併せて示している.ここで, 低水路粗度係数 $n_{1}$ と 高水敷粗度係数 $n_{2}$ には, 水深の変化に関わらず $h=1.0 m$ 時の粗度係数を用いる.つまり低水路粗度係数 $n_{1}$ には, $h=1.0 m$ の断面において $k_{1}=0.01 と し た$ 時に 算出した粗度係数を, 高水敷粗度係数 $n_{2}$ には, $h=1.0 m$ の断面において $k_{2}=0.1$ とした時に算出した粗 度係数を用いている. 複断面 A では低水路粗度係数 $n_{1}$ が 0.0170 , 高水敷粗度係数 $n_{2}$ が 0.0229 , 複断面 $\mathrm{B}$ では低水路粗度係数 $n_{1}$ が 0.0162 , 高水敷粗度係数 $n_{2}$ が 0.0217 となった. また, 合成粗度係数の算出方 法は , 以下の式を用いる .

$$
\begin{gathered}
N_{C 1}=\frac{R_{C}^{\frac{2}{3}} A}{\sum \frac{1}{n_{i}} R_{i}^{\frac{2}{3}} A_{i}} \\
N_{C 2}=\frac{\left(\sum P_{i} n_{i}^{3 / 2}\right)^{2 / 3}}{P^{2 / 3}}
\end{gathered}
$$

ここに， $N_{C 1}$ :(11)式の合成粗度式によって算出した粗 度係数, $N_{C 2}$ : (12)式の合成粗度式によって算出した粗 度係数, $R_{C}$ : 井田の合成径深 ${ }^{2)}, A_{1}$ : 各分割断面の面 積, $n_{i}$ : 各分割断面の粗度係数, $R_{i}$ : 各分割断面の径 深, $P_{i}$ : 各分割断面の潤辺長である.(11)式を用いる場 合には，低水路護岸の位置に鉛直線を引いたように，断 面が分割されることになる．一方，(12)式の場合には， 2 つの粗度係数を兴の潤辺長て比例配分することになる． (11)式を用いる場合には, 単純, 幅広断面ともに合成粗 度值は過小評価の傾向にある.(12)式を用いる場合，水 位が高水敷を超えるあたりで僅かに過大評価になってい るが, 複断面 $\mathrm{A}$ においては水深が $h=1.5 m$ を, 複断面 B においては水深が $h=2.0 m$ を超えるあたりて過小評 価に転じている．しかしながら, 総じて(12)式は(11)式 より良好な予測值となっていることがわかる．

また , 横断方向の運動量輸送による干跤効果を考慮し た福岡らの手法 ${ }^{2)}$ によっても合成粗度を算出した . 混

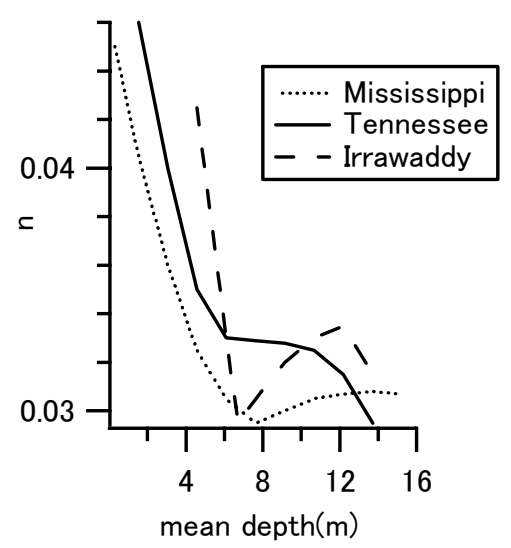

図-8 平均水深による粗度係数の変動

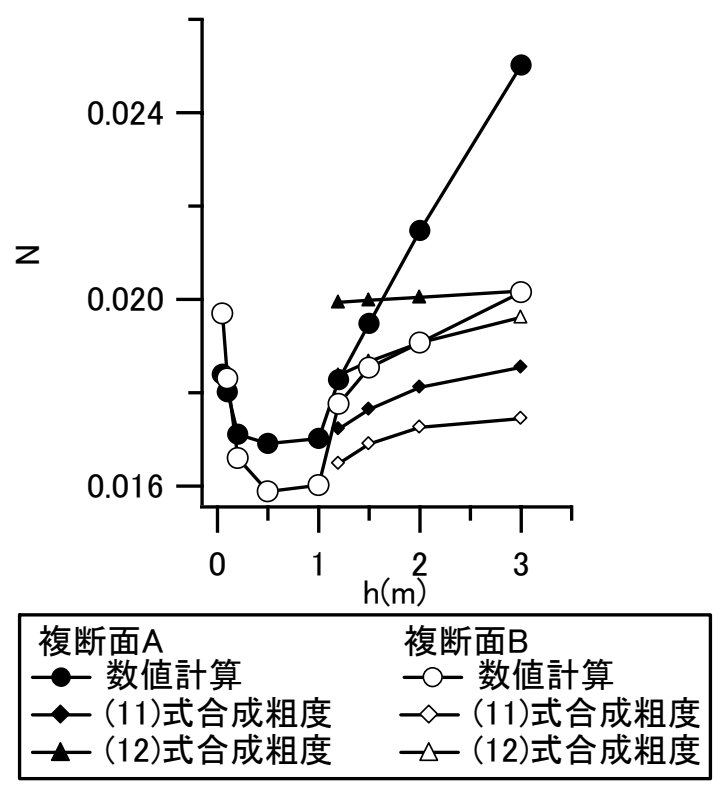

図-9 水深による粗度係数変動の再現

合係数 $f$ を变化させて数値計算結果と比較した . 図-10， 图-11は光れ光れ複断面Aと複断面Bの結果である。複断 面Bでは $f=0.04$ の時，計算結果と合成粗度値は一致し た . 福岡らは低水路幅の全水路幅に対する比率が $0.5 の$ 時, 0.1〜0.2という值を推奨しているが, 今回の計算結 果ではこれより小さい值となった . 複断面Aでは $f$ を一 定值にすると計算結果の変動傾向を再現することはでき なかった .

（4）合成粗度法の誤差に関する検討 次式を用いて合成粗度法の誤差を算定する．

$$
E=\frac{N_{S}-N_{C 1}}{N_{S}}
$$

ここに, $N_{S}$ : 数値計算によって算出した粗度係数であ る.このEの值がプラスである場合 , 合成粗度法を用 
いて求めた粗度係数值が, 過小評価となっていることを 示している.ここでの低水路粗度係数 $n_{1}$ と高水敷粗度 係数 $n_{2}$ は図-7の結果を用いている.

図-12に, 高水敷粗度係数と低水路粗度係数との比 $n_{2} / n_{1}$ と $E$ との関係を示している . 同図より，複断面 $\mathrm{A}$ よりも複断面Bの方が $E$ の值が大きいことが分かる. 図-9の $h=2.0 m$ では複断面Aの方か複断面Bよりも誤差 が大きいことから，矛盾しているように見えるかもしれ ないが, 図-9では低水路粗度係数と高水敷粗度係数を水 深に関わらず一定值としていることか関係していると考 えられる. また複断面 $\mathrm{A}$, 複断面 $\mathrm{B}$ もに, 粗度係数の 比が大きくなるにつれてEが大きくなっていること， $n_{2} / n_{1}=1$ では $E=0$ となっていることがわかる .

\section{5. まとめ}

本論文では, 汎用の数值計算ソフトウエアを用いて， 複断面開水路のマニングの粗度係数に関する数値計算を 行った . 水深による粗度係数の変動傾向, 合成粗度法を 用いた場合の粗度係数の誤差に関して考察を行った .

水深による粗度係数の変動傾向としては, 水深の小 さい範囲では水深の増加とともに粗度係数は減少し, 水 深か高水敷の高さ以上になると粗度係数力増加するとい う，実河川て観察される傾向と同樣の傾向が再現された . また複断面 A，Bともに合成粗度係数は(11) 式よりも (12) 式の方が, 数値計算の結果により近い值となった . 断面形状によっては，運動量交換を考慮した合成粗度法 は数値計算結果の傾向を良好に再現した . (11)式の合成 粗度式の誤差については, $h=2.0 m$ 時の誤差を調査し た結果， $n_{2} / n_{1}$ が大きくなるほど $E$ は大きくなるという ことが分かった . また , 複断面Bの方が複断面Aよりも Eの值が大きいことか確認された .

本研究では, 低水路と高水敷との間の運動量交換に重 要な役割を果たす組織的流れ力粗度係数に及ぼす影響に ついて全く検証を行っていない . このことは今後の検 討課題としたい.

\section{参考文献}

1) 藤田光一, 橋本宏, 浅野富夫, 坂野章 : 複断面河道におけ る合成粗度係数と低水路水深との関係, 土木学会年次学術 講演会講演概要集第2部，40巻，pp. 313-314, 1985

2) 土木学会編 : 水理公式集, 第2編, 土木学会, 1999

3) Ponnambalam Rameshwaran and Pamela S.Naden: ThreeDimensional Numerical Simulation of Compound Channel Flows , Journal Of Hydraulic Engineering, Vol.129, Issue 8, pp.645-652 , 2003

4) 国土交通省河川局 : 美しい山河を守る災害復旧基本方針， 参考資料 I , pp.6, 2006
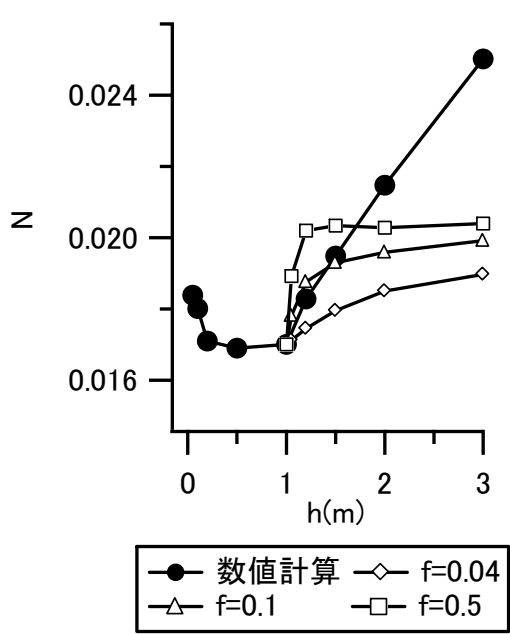

図-10 運動量交換を考慮した合成粗度（複断面A）
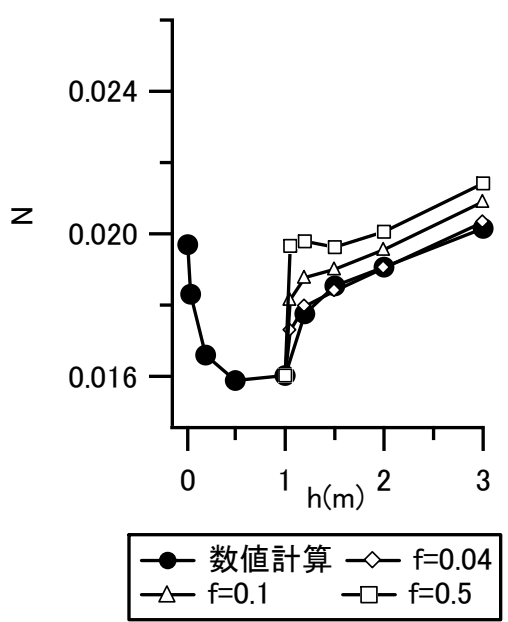

図-11 運動量交換を考慮した合成粗度( 複断面B)

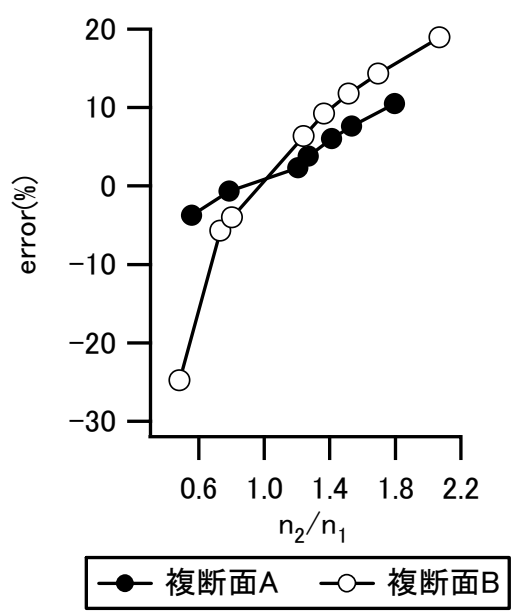

図-12 h=2 Onhこおける合成粗度法の誤差

5) 山岡勲 : 河床の粗度について, 北海道開発局土木試験所 月報第100号，pp.8. 1961 